\title{
Auditul intern
}

\section{- partea a II-a -}

\section{Conf. univ. dr. Mirela PĂUNESCU}

Academia de Studii Economice din București

\begin{abstract}
According to the international view, the aim of the internal audit is "to enhance and protect the organizational value by providing assurance, advice and advanced knowledge through objective principles based on risk".

This article presents aspects regarding the internal audit of an entity, its underlying principles, the differences between the internal audit, the financial audit and the internal control, the role of the internal audit in corporate governance, the most important types of internal audit engagements and their components, as well as the main stages of an internal audit engagement.
\end{abstract}

Key terms: internal audit, assurance engagements, advisory engagements, corporate governance, International Standards on Internal Auditing

Termeni-cheie: audit intern, misiuni de asigurare, misiuni de consiliere, guvernanță corporativă, Standardele Internaționale de Audit Intern

Clasificare JEL: M42

To cite this article: Mirela Păunescu, Auditul intern (II), CECCAR Business Review, № 4/2020, pp. 46-55, DOI: http://dx.doi. org/10.37945/cbr.2020.04.06

\section{Rolul auditului intern în guvernanța corporativă}

Din definiția sa reiese că auditul intern joacă un rol fundamental în guvernanța corporativă, el fiind menit să ofere asigurare prin evaluarea și raportarea eficienței proceselor de management al riscului, control intern și guvernanță astfel încât să sprijine entitatea pentru a-și atinge obiectivele.

Rapoartele obiective și competente ale funcției de audit intern privind guvernanța, riscul și controlul intern sunt sursa unor schimbări pozitive în cadrul entității (https://na.theiia.org/about-ia/PublicDocuments/ Internal-Auditings-Role-in-Corporate-Governance.pdf), inspirând încredere organizațională și permițând luarea unor decizii competente și informate. În plus, auditul intern poate adăuga valoare prin furnizarea de servicii de consiliere menite să îmbunătățească procesele de management al riscului, control intern și guvernanță.

Potrivit ISA 610 Utilizarea activității auditorilor interni, funcția de audit intern desfășoară activități de asigurare și consultanță care au rolul de a evalua și îmbunătăți eficacitatea proceselor de management al riscului, control intern și guvernanță ale entității, adică activități de:

- evaluare a procesului de guvernanță, cum ar fi evaluarea gradului de realizare a obiectivelor, a culturii organizaționale, a procesului de comunicare a informațiilor privind riscul și controlul și a celui de comunicare dintre persoanele responsabile cu guvernanța, auditorii externi și interni și conducere etc.; 
- gestionare a riscului, cum ar fi identificarea și evaluarea expunerilor semnificative la risc și contribuția la îmbunătățirea gestionării riscului și controlului intern;

- asistare a entității în detectarea fraudei;

- control intern, cum ar fi responsabilități specifice pentru revizuirea controalelor, evaluarea funcționării acestora și furnizarea de recomandări de îmbunătățire;

- examinare a informațiilor financiare, cum ar fi revizuirea procedurilor utilizate pentru identificarea, recunoașterea, evaluarea, clasificarea și raportarea acestora sau teste de detaliu ale tranzacțiilor, soldurilor și elementelor individuale;

- revizuire a operațiunilor de exploatare, cum ar fi cea a economicității, eficienței și eficacității proceselor entității;

- revizuire a conformității cu normele în vigoare, cum ar fi cea a conformității cu legile, reglementările și alte cerințe externe, cu politicile și procedurile interne etc.

Auditul intern joacă un rol important în procesul de identificare, evaluare și prioritizare a riscurilor, precum și în monitorizarea implementării procedurilor de control intern, a celor privind managementul riscurilor și a proceselor de guvernanță.

Totuși, pentru ca auditul intern să își îndeplinească rolul strategic, trebuie avute în vedere câteva considerente. Doar dacă este independent (lipsit de influențe din afară) auditul intern își poate efectua evaluările în mod obiectiv, oferind conducerii și celor însărcinați cu guvernanța corporativă o apreciere imparțială și critică asupra proceselor de management al riscului, control intern și guvernanță, precum și recomandări pentru îmbunătățirea acestora. Totodată, numai având competența și resursele necesare va putea să ofere servicii la calitatea cerută.

Aplicarea standardelor emise de IIA asigură eficacitatea funcției de audit intern și contribuția acesteia la guvernanța corporativă a entității.

\section{Legătura dintre auditul intern și sistemul de control intern}

Controlul intern este definit ca fiind un proces efectuat de consiliul de administrație, conducere și întregul personal al entității, menit să furnizeze o asigurare rezonabilă cu privire la îndeplinirea obiectivelor organizației, urmărind eficiența și eficacitatea operațiunilor, credibilitatea raportării financiare și conformitatea cu legile și reglementările aplicabile. Bunele practici dictează ca entitățile să includă controlul intern, într-o formă sau alta, în fiecare activitate și să îl formalizeze prin proceduri operaționale de lucru și prin instrucțiuni de realizare cărora trebuie să le corespundă activități de control intern.

Ca atare, activitățile de control intern sunt cele corespunzătoare de control implementate la nivel de proces, concepute astfel încât să asigure reducerea riscurilor care pot afecta negativ realizarea obiectivelor entității. Activitățile de control intern trebuie corelate cu apetitul de risc specific societății, care este stabilit de cei însărcinați cu guvernanța corporativă, transpunând voința acționarilor. În practică, activitățile de control trebuie implementate pentru protejarea împotriva riscurilor inacceptabile pentru entitate sau pentru respectarea reglementărilor aplicabile în vederea asigurării conformității cu cadrul normativ.

După cum am precizat, o parte a definiției auditului intern se referă la faptul că acesta ajută organizația în îndeplinirea obiectivelor sale printr-o abordare sistematică și metodică ce evaluează și îmbunătățește eficacitatea proceselor de management al riscului, control și guvernanță.

Multe entități înființează funcții de audit intern ca parte a structurilor lor de control intern. Conform ISA 610, auditul intern poate juca un rol semnificativ în evaluarea controlului intern, fiindu-i alocate responsabilități specifice pentru revizuirea controalelor, evaluarea funcționării acestora și efectuarea de recomandări privind îmbunătățirea. 
În îndeplinirea acestor responsabilități, funcția de audit intern oferă asigurare privind controlul, prin intermediul raportărilor pe care aceasta le face în legătură cu rezultatele evaluării controlului intern.

Auditorul intern trebuie să înțeleagă și să testeze mediul de control, procedurile de evaluare a riscurilor implementate de entitate, sistemul de informare și comunicare și metodele de monitorizare și evaluare a sistemului de control intern. Înțelegerea trebuie să vizeze modul în care mecanismele de control au fost proiectate, iar testarea urmărește dacă acestea au fost aplicate și dacă funcționează eficient.

Probele pentru evaluarea și testarea sistemului de control intern se obțin din informațiile și documentele (inclusiv răspunsurile la chestionare și declarația conducerii entității auditate/responsabilului structurii auditate) obținute la începutul misiunii de audit, precum și din cele obținute pe parcursul derulării misiunii.

După testarea controalelor interne, auditorul intern poate raporta despre gradul de adecvare al controlului intern la specificul și particularitățile entității. Evaluarea poate viza vulnerabilitatea controlului intern (redusă, medie, ridicată), eficiența acestuia (suficient, insuficient sau cu lipsuri grave) ori impactul financiar la care este expusă societatea ca urmare a unei eventuale deficiențe a controlului intern (impact redus, mediu, important).

Auditorul trebuie să adapteze criterii de apreciere calitative și cantitative la specificul entității (cum ar fi să decidă asupra nivelurilor pentru pragurile valorice în vederea estimării impactului financiar, dacă acesta este redus sau ridicat etc.). Pot fi utilizate mai multe valori (de regulă, nu mai mult de cinci). De asemenea, este permisă folosirea de culori sau numere care să aibă semnificații similare cu cele prezentate anterior (referitor la nivelul de adecvare). De regulă, culoarea roșu înseamnă că managementul trebuie să ia o măsură urgentă deoarece ineficiența controlului intern poate afecta semnificativ entitatea, culoarea galben arată că cei din conducere trebuie să ia măsuri, nu neapărat urgente, deoarece deficiențele controlului intern pot afecta societatea (nu neapărat semnificativ sau pe termen scurt), iar culoarea verde indică faptul că, în afară de nevoia unor îmbunătățiri minore, sistemul de control intern funcționează eficient. în cazul în care auditorul intern monitorizează deficiențele pe cinci niveluri, nu pe trei, suplimentar pot fi adăugate portocaliu (nivel intermediar între roșu și galben) și verde deschis (nivel intermediar între verde și galben).

Aprecierile controlului intern (care sunt fie făcute într-un raport separat, fie incluse ca parte a raportului pregătit pentru fiecare misiune de audit intern) se pot exprima în mai multe moduri. Spre exemplu, în urma testării controlului intern (de regulă, pentru un anumit proces sau o anumită activitate), auditorul intern poate să-I găsească corespunzător, insuficient sau cu lipsuri grave. Pot fi utilizate mai multe trepte (intervale sau valori), în funcție de metodologia adoptată de auditorul intern.

Pentru ca auditorul intern să considere corespunzător sistemul de control intern și de management al riscurilor existent în cadrul procesului/structurii auditat(e), el trebuie să se asigure că:

- acesta este proiectat și operează într-o asemenea manieră încât obiectivele procesului/structurii respectiv(e) sunt atinse;

- riscurile-cheie sunt identificate și gestionate eficace;

- slăbiciunile identificate expun procesul/structura auditat(ă) la un nivel general al riscului rezidual scăzut;

- nu se impune ca managementul să întreprindă acțiuni sau să ia măsuri de corecție semnificative (totuși pot exista îmbunătățiri ale controlului).

Pentru ca auditorul intern să considere insuficient sistemul de control intern și de management al riscurilor existent în cadrul procesului/structurii auditat(e), el trebuie să concluzioneze că:

- acesta este, în linii mari, proiectat și operează într-o asemenea manieră încât obiectivele procesului/ structurii respectiv(e) sunt atinse; 
- riscurile-cheie sunt identificate și gestionate eficace;

- slăbiciunile identificate expun procesul/structura auditat(ă) la un nivel general al riscului rezidual scăzut spre mediu;

- se impune ca managementul să întreprindă o serie de acțiuni și să ia măsuri de corecție semnificative într-un anumit interval de timp.

Pentru ca auditorul intern să considere că sistemul de control intern și de management al riscurilor existent în cadrul procesului/structurii auditat(e) are lipsuri grave, el trebuie să constate că:

- acesta este proiectat sau operează insuficient pentru ca obiectivele procesului/structurii respectiv(e) să fie atinse;

- riscurile-cheie nu sunt complet identificate sau nu sunt gestionate eficace;

- slăbiciunile identificate expun procesul/structura auditat(ă) la un nivel general al riscului mediu spre ridicat;

- se impune ca managementul să întreprindă anumite acțiuni și să ia măsuri de corecție semnificative într-un interval de timp relativ scurt și, în mod excepțional, se cer acțiuni urgente.

\section{Auditul intern în context românesc}

Legislația în vigoare în țara noastră stabilește care sunt societățile care au obligația de a organiza activitatea de audit intern și ce reprezintă pentru ele această activitate.

Astfel, art. 65 alin. (7) din Legea nr. 162/2017 privind auditul statutar al situațiilor financiare anuale și al situațiilor financiare anuale consolidate și de modificare a unor acte normative prevede că entitățile ale căror situații financiare anuale sunt supuse auditului statutar au obligația de a organiza și de a asigura exercitarea activității de audit intern, potrivit cadrului legal, care este reprezentat de Ordonanța de urgență a Guvernului nr. 75/1999 privind activitatea de audit financiar, republicată, cu modificările și completările ulterioare, și de normele secundare emise de Camera Auditorilor Financiari din România.

Conform art. 23 din OUG nr. 75/1999, responsabilii pentru organizarea activității de audit intern, coordonarea lucrărilor/angajamentelor și semnarea rapoartelor de audit intern trebuie să aibă calitatea de auditor financiar. CAFR a adoptat Standardele Internaționale de Audit Intern emise de Institutul Auditorilor Interni, astfel încât acestea au devenit obligatorii pentru toți auditorii financiari în desfășurarea activităților de audit intern.

Potrivit art. 44 alin. (1) lit. b) din Legea nr. 162/2017, în cazul în care societățile ale căror situații financiare anuale sunt supuse auditului financiar nu își respectă obligația de a organiza auditul intern potrivit normelor elaborate de CAFR, sancțiunea poate varia între 50.000 lei și 100.000 lei.

Care sunt societățile care au obligația auditării? Cele de interes public (așa cum sunt identificate de Legea nr. 162/2017 sau de Legea contabilității nr. 82/1991, republicată, cu modificările și completările ulterioare), cele care depășesc anumite criterii de mărime (prevăzute în Ordinul ministrului finanțelor publice nr. 1.802/2014 pentru aprobarea Reglementărilor contabile privind situațiile financiare anuale individuale și situațiile financiare anuale consolidate, cu modificările și completările ulterioare), societățile pe acțiuni care optează pentru sistemul dualist de administrare, alte societăți sau entități obligate prin legislația aplicabilă lor.

Consiliul de administrație (sau directoratul) trebuie să prezinte auditorilor interni și auditorilor financiari cu cel puțin 30 de zile înainte de ziua stabilită pentru ședința adunării generale situația financiară anuală pentru exercițiul financiar precedent, însoțită de raportul lor și de documentele justificative.

Printr-un raport, auditorii interni vor aduce la cunoștință membrilor consiliului de administrație neregulile în administrație și încălcările dispozițiilor legale și ale prevederilor actului constitutiv pe care le constată, iar 
cazurile mai importante le vor aduce la cunoștință adunării generale. În raport sunt incluse și rezultatele activității lor, precum și propunerile pe care le consideră necesare cu privire la situațiile financiare și repartizarea profitului.

În cazul societăților în care au fost desemnați auditori interni, orice acționar are dreptul să reclame acestora faptele despre care crede că trebuie verificate. Auditorii interni vor ține cont de ele la întocmirea raportului către consiliul de administrație, respectiv consiliul de supraveghere. În cazul în care reclamația este făcută de acționari reprezentând, individual sau împreună, cel puțin $5 \%$ din capitalul social ori o cotă mai mică, dacă actul constitutiv prevede astfel, auditorii interni sunt obligați să verifice faptele reclamate, iar dacă sunt confirmate vor fi consemnate într-un raport ce va fi comunicat consiliului de administrație, respectiv consiliului de supraveghere, și pus la dispoziția adunării generale. În această situație, consiliul de administrație, respectiv consiliul de supraveghere, este obligat să convoace adunarea generală.

\section{Desfășurarea unei misiuni de audit intern}

Înainte de a discuta despre misiunile de audit intern, este relevant să descriem procesul de audit intern. Acesta se poate urmări pe cinci etape distincte, prezentate mai jos:

\begin{tabular}{|l|l|}
\hline \multicolumn{1}{|c|}{ Etapă } & \multicolumn{1}{c|}{ Descriere } \\
\hline Activități de bază & $\begin{array}{l}\text { - existența unei carte a auditului intern de unde să reiasă misiunea și valorile } \\
\text { acestuia }\end{array}$ \\
\hline Planificare & $\begin{array}{l}\text { - înțelegerea obiectivelor companiei } \\
\text { - evaluarea riscurilor } \\
\text { - pregătirea unui plan de audit (preferabil multianual) } \\
\text { - revizuirea continuă a riscurilor }\end{array}$ \\
\hline Activități de teren & $\begin{array}{l}\text { - înțelegerea activității care va fi auditată } \\
\text { - deciderea modului de abordare }\end{array}$ \\
\hline Raportare & $\begin{array}{l}\text { - documentarea } \\
\text { - sintetizarea aspectelor semnificative }\end{array}$ \\
\hline Urmărirea calității & $\begin{array}{l}\text { - discuții cu responsabilul pentru activitate } \\
\text { - } \text { indicatorii de calitate }\end{array}$ \\
\hline
\end{tabular}

Mai jos sunt prezentate câteva noțiuni relevante:

Carta auditului intern este documentul oficial care definește scopul, autoritatea și responsabilitățile activității de audit intern. În cadrul ei trebuie să fie stabilite poziția auditului intern în organizație, tipul relației de raportare funcțională a șefului departamentului de audit intern față de consiliu, autorizarea accesului nelimitat la înregistrări, personal și active relevante pentru executarea misiunilor, precum și definirea sferei de cuprindere a activităților de audit intern. Aprobarea finală a cartei trebuie să fie făcută de consiliul de supraveghere.

Planificarea activității de audit intern reprezintă procesul de determinare a priorităților acesteia, în funcție de care se decide care sunt misiunile în care se va angaja departamentul de audit intern în anul respectiv (sau în anii următori, în cazul planificării multianuale recomandate). Șeful departamentului de audit intern va stabili un plan bazat pe riscuri pentru a determina prioritățile activității de audit intern, care trebuie să fie în 
concordanță cu obiectivele organizației. În acest scop este necesar să se consulte cu conducerea superioară și cu consiliul pentru a înțelege strategiile organizației, obiectivele-cheie și riscurile asociate, precum și procesele de administrare a riscurilor. Suplimentar, se poate consulta și cu alte părți interesate.

Tot șeful departamentului de audit intern este responsabil cu revizuirea și ajustarea planului ca răspuns la schimbările survenite cu privire la activitățile, riscurile, operațiunile, programele, sistemele și controalele organizației.

În stabilirea planului de audit (preferabil multianual) se vor lua în considerare:

- riscurile semnificative pentru entitate;

- așteptările și doleanțele conducerii;

- cerințele legislative;

- proiectele semnificative aflate în curs de implementare sau cele planificate;

- modificările majore care intervin în structura organizațională sau la nivel operațional;

- incidențele ori disfuncționalitățile apărute în activitatea părților interesate;

- deficiențele identificate de organele de control sau de supraveghere ori de auditorul extern;

- resursele existente;

- rezultatele misiunilor trecute.

În ceea ce privește riscurile semnificative pentru entitate, departamentul de audit intern identifică, actualizează și evaluează riscurile relevante utilizând raționamentul profesional, cunoștințele, experiența și informațiile legate de activitățile respective, acumulate în misiunile de audit anterioare sau puse la dispoziție de departamentul de management al riscului (dacă există).

În cazul în care există un proces de gestionare a riscurilor realizat de conducerea entității, departamentul de audit intern ia în considerare riscurile identificate și nivelul lor stabilit de entitate, putând identifica sau evalua diferite părți din ele. De regulă, în aceste situații se discută cu cei din conducere pentru a lămuri diferențele. Dacă un astfel de proces nu există, departamentul de audit intern are responsabilitatea identificării riscurilor relevante la evaluarea acestora și la selectarea activităților ce vor fi incluse în planul de audit.

Planul de audit trebuie prezentat celor din conducere, care au posibilitatea de a formula obiecții de care auditorul intern poate ține cont, și trimis pentru aprobare comitetului de audit (sau consiliului de administrație).

Raportarea către comitetul de audit (consiliul de administrație) este o etapă foarte importantă a activității de audit intern. Astfel, o dată pe an (de regulă, la final de an; perioada este prevăzută în Carta auditului intern), departamentul (sau funcția de audit, dacă este externalizată) pregătește un raport care cuprinde o sinteză a activității sale și gradul de îndeplinire a operațiunilor stabilite prin planul anual. Pe lângă această sinteză, raportul mai conține:

- o prezentare succintă a celor mai semnificative probleme identificate de auditorii interni și domeniile în care au fost constatate acestea;

- rata de implementare a recomandărilor misiunilor de audit intern, evidențiindu-se recomandările neimplementate;

- recomandările pentru care structura de audit nu a ajuns la un consens cu conducerea celei auditate ori care au fost refuzate de aceasta;

- alte comentarii considerate semnificative;

- considerații privind managementul riscurilor și sistemul de control intern al structurilor organizatorice auditate, în funcție de situația opiniilor generale acordate în misiunile de audit;

- rezultatele obținute în realizarea celorlalte activități planificate; 
- modul de utilizare a resurselor (materiale, financiare, umane etc.) pentru realizarea activității, inclusiv din punctul de vedere al încadrării cheltuielilor efectuate în prevederile bugetare aprobate, evidențiindu-se motivele pentru variațiile majore, precum și măsurile întreprinse sau care este necesar a fi întreprinse pentru remediere;

- alte aspecte relevante.

Desfășurarea unei misiuni de audit intern (de asigurare) poate fi urmărită pe parcursul mai multor etape, așa cum se poate observa în schema prezentată mai jos:

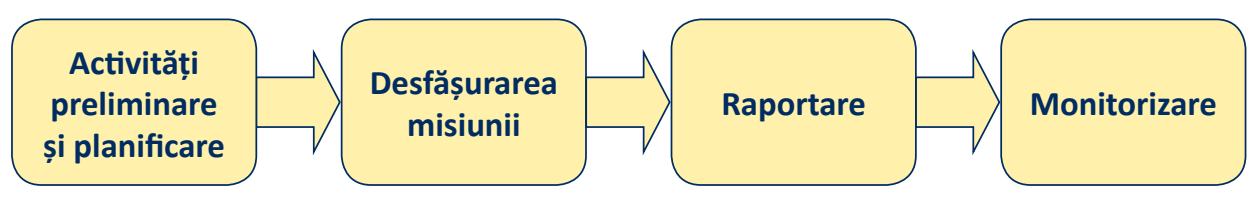

Activitățile preliminare și planificarea cuprind, de regulă:

- inițierea auditului intern, care poate consta în notificarea responsabilului cu procesul/structura auditat(ă) cu privire la misiunea ce urmează să se desfășoare;

- colectarea și prelucrarea prealabilă a informațiilor necesare misiunii;

- analiza riscurilor;

- desfășurarea ședinței de deschidere;

- elaborarea programului de audit.

În notificarea inițială i se solicită responsabilului/structurii auditate transmiterea unei liste cu reglementările relevante (interne sau externe), documentarea controlului intern, precum și alte informații care sunt considerate utile pentru desfășurarea misiunii.

Elaborarea programului de audit trebuie să țină cont de principalele riscuri identificate și evaluate la nivelul structurii/procesului auditat(e), precum și de alte considerente, cum ar fi resursele necesare, complexitatea activității etc.

Practic, se consideră că misiunea de audit intern începe la data ședinței de deschidere.

Desfășurarea misiunii cuprinde:

- colectarea informațiilor, documentelor și probelor relevante;

- aplicarea procedurilor (testelor);

- analiza rezultatelor;

- documentarea;

- revizuirea programului de audit pregătit;

- desfășurarea ședinței de închidere.

Auditorii interni pot aplica procedurile stabilite prin programul de audit fie integral asupra populației, fie pe bază de eșantion. Cele mai utilizate proceduri sunt (lista nu este exhaustivă): interviul, observarea, inspecția, investigarea, verificarea, testele walk-through, examinarea documentelor și înregistrărilor, analiza datelor și informațiilor, reefectuarea sau recalcularea, confirmarea și procedurile analitice.

În faza de raportare, auditorii interni parcurg următoarele etape:

- pregătirea proiectului de raport de audit intern (variantă provizorie) și transmiterea lui către structura auditată;

- desfășurarea ședinței de reconciliere;

- întocmirea raportului final și transmiterea acestuia către structura auditată și eventualii responsabili. 
Raportul de audit, produsul final al întregului proces de audit, este documentul care reunește rezultatele activităților de audit, opinia auditorului și recomandările sale. Opinia poate fi exprimată printr-un rating, printr-o concluzie sau printr-o altă descriere a rezultatelor privind, la nivel general, procesele de guvernanță, managementul riscului și/sau controlul intern.

Monitorizarea presupune:

- urmărirea modului în care s-au transpus în practică recomandările raportului de audit intern și a măsurii în care s-a făcut acest lucru;

- actualizarea evaluării riscurilor.

În literatura de specialitate pot fi găsite și alte modalități de organizare a etapelor misiunilor de audit intern.

\section{Organizarea ierarhică a structurii de audit intern}

În literatura de specialitate este acceptat faptul că auditorul intern nu este, de regulă, la fel de independent ca cel financiar. Spre exemplu, ISA 610 consideră că acesta este un motiv pentru care auditorul financiar nu se poate baza doar pe activitatea auditorului intern. În cazul în care funcția de audit intern este externalizată, independența este mai crescută. Dacă auditorul intern este angajatul societății, plata salariului și impunerea unor condiții de desfășurare a activității fac ca independența sa să nu fie absolută.

Întrucât este important ca auditorul intern să iș̦i mențină obiectivitatea și independența în orice condiții, printr-o organizare ierarhică adecvată se poate obține acest lucru. Astfel, din punct de vedere organizațional, chiar dacă sub aspect administrativ auditul intern este subordonat managementului, sub aspect funcțional (al raportării și coordonării activității sale) acesta trebuie să fie subordonat direct persoanelor însărcinate cu guvernanța corporativă (dacă există, comitetului de audit, consiliului de administrație, consiliului de supraveghere). Reamintim că în țara noastră societățile pe acțiuni pot să își organizeze comitete de audit din care trebuie să facă parte minimum doi membri, iar dintre aceștia cel puțin unul este necesar să dețină experiență în aplicarea principiilor contabile sau în audit financiar. Există și cerințe privind existența unui membru independent sau a unor membri neexecutivi în acest comitet.

Independența organizațională trebuie să le permită auditorilor interni inclusiv să desfășoare angajamente de evaluare a modului în care entitatea este efectiv condusă și să raporteze eventualele iregularități descoperite fără teama de a-și pierde locul de muncă.

Standardele Internaționale de Audit Intern și regulile de bună practică recomandă ca șeful funcției de audit intern să răspundă direct în fața președintelui comitetului de audit. Acest comitet aprobă și planificarea misiunilor de audit intern pentru anii următori și este destinatarul raportului de activitate în care sunt sintetizate principalele constatări ale departamentului de audit intern legate de eficiența modului în care este condusă societatea.

Totuși, indiferent de modul de organizare a funcției de audit intern, pentru ca aceasta să fie eficace, trebuie să beneficieze de sprijinul conducerii și al celor însărcinați cu guvernanța corporativă, care reiese din modul în care aceștia colaborează cu auditorul intern și îndeamnă salariații companiei la o colaborare transparentă cu el.

Funcția de audit intern trebuie să beneficieze de resurse adecvate (umane, financiare, materiale) și de condiții optime de lucru. Este necesar ca salariații să știe că au obligația de a pune la dispoziția auditorilor interni informațiile solicitate, conducerea fiind cea responsabilă pentru cunoașterea și respectarea de către angajați a acestei îndatoriri, precum și că trebuie să colaboreze cu auditorii atunci când le este solicitat (spre exemplu, să comunice în timp util și transparent). 
Cei din conducere vor comunica periodic cu auditorii interni, făcându-le cunoscute deciziile importante luate, dezvoltarea sau modificarea de procese și sisteme, stadiul de implementare a planului de acțiune stabilit prin rapoartele de audit, schimbările de obiective, suspiciunile de fraudă etc.

Funcția de audit intern poate fi internalizată sau externalizată. Decizia este una complexă și trebuie să fie luată în urma unei analize a avantajelor și dezavantajelor opțiunilor examinate. Societăți aflate în diverse stadii de dezvoltare vor concluziona diferit în ceea ce privește externalizarea funcției, care poate fi parțială sau totală.

Principalele avantaje și dezavantaje, sintetizate, ale externalizării funcției de audit intern sunt prezentate în continuare:

\begin{tabular}{|c|c|}
\hline Avantaje & Dezavantaje \\
\hline \multirow[t]{2}{*}{$\begin{array}{l}\checkmark \text { Calitatea funcției de audit intern este probabil } \\
\text { mai bună. }\end{array}$} & $\begin{array}{l}\checkmark \text { Salariații auditori interni cunosc mai bine } \\
\text { o societate complexă. }\end{array}$ \\
\hline & $\begin{array}{l}\checkmark \text { Fluctuația de personal al firmei de audit } \\
\text { afectează calitatea auditului. }\end{array}$ \\
\hline $\begin{array}{l}\checkmark \text { Se fac economii de costuri în cazul entităților mai } \\
\text { puțin complexe. }\end{array}$ & $\begin{array}{l}\checkmark \text { La societățile mari, costurile sunt mai ridicate } \\
\text { decât în cazul internalizării. }\end{array}$ \\
\hline \multicolumn{2}{|l|}{$\checkmark$ Independența și obiectivitatea sunt mai crescute. } \\
\hline & $\begin{array}{l}\checkmark \text { Confidențialitatea informațiilor este mai greu } \\
\text { de păstrat. }\end{array}$ \\
\hline & $\begin{array}{l}\checkmark \text { Poate exista reticență din partea salariaților } \\
\text { societății. }\end{array}$ \\
\hline$\checkmark$ Accesul la resurse de calitate este mai facil. & $\begin{array}{l}\checkmark \text { Poate fi dificil să se găsească o firmă de audit } \\
\text { cu suficiente resurse (și adecvate) în cazul } \\
\text { societăților mari și complexe. }\end{array}$ \\
\hline \multicolumn{2}{|l|}{$\checkmark$ Accesul la resurse diverse este mai facil. } \\
\hline \multicolumn{2}{|l|}{$\checkmark$ Resursele interne sunt degrevate. } \\
\hline \multicolumn{2}{|l|}{$\checkmark$ Activitatea entității se simplifică. } \\
\hline \multirow[t]{2}{*}{$\begin{array}{l}\checkmark \text { Controlul auditorilor interni este efectuat, } \\
\text { de regulă, de un organism profesional. }\end{array}$} & $\begin{array}{l}\checkmark \text { Este mai greu de controlat o funcție atunci } \\
\text { când este externalizată decât atunci când este } \\
\text { internalizată. }\end{array}$ \\
\hline & $\begin{array}{l}\checkmark \text { Disponibilitatea auditorului intern în cazul } \\
\text { serviciilor externalizate este mai mică decât } \\
\text { în cazul celui angajat. }\end{array}$ \\
\hline
\end{tabular}

Externalizarea parțială presupune completarea resurselor interne cu unele externe. Astfel, există posibilitatea ca un prestator extern să dețină responsabilitatea finală pentru funcția de audit intern a societății sau doar să vină în completare cu resursele necesare. Această completare poate viza activități curente sau societatea poate decide să externalizeze doar anumite investigații (cum ar fi cele legate de fraudă) ori misiuni (cum ar fi cele privind sistemul IT, unde entitatea poate concluziona că nu există intern resursele necesare pentru a desfășura o misiune de complexitatea cerută). 
Fără a fi considerată externalizare, atunci când resursele departamentului de audit intern nu sunt suficiente, se poate apela la salariații companiei, însă doar cu respectarea anumitor restricții, cum ar fi obținerea aprobărilor pe cale administrativă sau utilizarea unui angajat în misiuni în care poate fi obiectiv, nefiind implicat în procesele respective.

\section{Bibliografie}

1. CAFR \& AAIR (2015), Ghid privind implementarea Standardelor Internaționale de Audit Intern, Editura CAFR, București.

2. Legea nr. $162 / 2017$ privind auditul statutar al situațiilor financiare anuale și al situațiilor financiare anuale consolidate și de modificare a unor acte normative, publicată în Monitorul Oficial nr. 548/12.07.2017.

3. Ordonanța de urgență a Guvernului nr. 75/1999 privind activitatea de audit financiar, republicată în Monitorul Oficial nr. 598/22.08.2003, cu modificările și completările ulterioare.

4. http://www.aair.ro/fisiere/standarde_2017_romana/Code_of_Ethics_Romanian.pdf

5. https://na.theiia.org/about-ia/PublicDocuments/Internal-Auditings-Role-in-Corporate-Governance.pdf

6. https://na.theiia.org/about-us/Pages/About-The-Institute-of-Internal-Auditors.aspx

7. https://na.theiia.org/standards-guidance/mandatory-guidance/Pages/Core-Principles-for-the-ProfessionalPractice-of-Internal-Auditing.aspx

8. https://na.theiia.org/standards-guidance/mandatory-guidance/Pages/Mandatory-Guidance.aspx

9. https://na.theiia.org/standards-guidance/Pages/Mission-of-Internal-Audit.aspx

10. https://na.theiia.org/standards-guidance/recommended-guidance/Pages/Strongly-RecommendedGuidance.aspx

11. https://na.theiia.org/translations/PublicDocuments/IPPF-Standards-2017-Romanian.pdf

$\stackrel{\leftrightarrow}{\hookrightarrow}$ Acest articol este preluat din lucrarea Guvernanța corporativă, managementul riscurilor și controlul intern, autor Mirela Păunescu, apărută la Editura CECCAR în anul 2019. 